\title{
Analysis of the first draft of the Moldovan Law on public-private partnerships*
}

\section{- Including an analysis of German and Russian legislation on public- private partnerships and an evaluation of compliance with the respective EU law}

\section{Introduction and general outline}

The public-private partnership phenomenon

An increasing recourse to public-private partnerships (in the following: PPP) can be detected throughout several European countries. ${ }^{1}$ Furthermore, this model has also found application in the Russian Federation ${ }^{2}$ and, very recently, in the Republic of Moldova, where a draft Law on PPPs has just been formulated. The term PPP encompasses a wide range of forms of co-operation between public authorities and private actors. Public authorities are facing budget constraints, so there is a need for private funding for the public sector. However, engagement in PPPs entails a potential loss of control for public authorities over projects.

Facing these challenges, different approaches exist to the provision of a concise legal framework and a detailed homogeneous regulation for PPPs. ${ }^{3}$ This analysis will give an overview of these different approaches, taking the draft Law on PPPs of the Republic of Moldova as a starting point and comparing the regulations of the developing body of law to those of the European Union, Germany and the Russian Federation.

\section{Objectives of the study and general outline}

The first objective is to provide an initial orientation in the fragmented area of PPPs at the Moldovan, European, German and Russian levels. With special regard to the new draft Law on PPPs in Moldova, the background and development of this body of law will be presented. The draft was developed within the implementation of the Partnership and Co-operation Agreement (PCA) and the European Neighbourhood Policy

* The comparative analysis in this article is a revised version of a statement delivered by Wolfgang Tiede as legal expert in the project 'Support for PCA and WTO implementation and for EU/Moldova European Neighbourhood Policy Action Plan (ENPAP)', at the request of the Centre for Legal Approximation.

1 European Commission (publ.) (2004) Green Paper on public-private partnerships and Community law on public contracts and concessions COM(2004)254: 3.

2 Tiede, Wolfgang (2007) 'Rechtliche Rahmenbedingungen für Public Private Partnerships bei Infrastrukturprojekten in der Russischen Föderation' in Jahrbuch für Ostrecht: 55 et seq.

3 For the European Union, see: European Commission (publ.) (2004) op. cit. p. 3; for Germany, see: Fleckenstein, Martin (2006) 'Abbau von Hemmnissen für Public Private Partnership: Das ÖPP-Beschleunigungsgesetz' in Deutsche Verwaltungsblätter p. 76; for the Russian Federation, see: Tiede op. cit. p. 55. 
(ENP), which aims at avoiding the emergence of new dividing lines between the enlarged EU and her neighbours and instead strengthening the prosperity, stability and security of all concerned, so it is also of interest as to what extent the Moldovan body of law corresponds with the European regulations. A short comparative analysis of the Moldovan draft Law with regulations on PPPs in Germany and the Russian Federation, where a law on PPPs has been in force since 2005, will complete the overview.

\section{Moldovan draft Law on Public-Private Partnerships}

Moldova is the poorest country in Europe and suffers from weak state structures which constrain sustainable economic growth. The reason is the lack of foreign direct investment and local investment. Investors still perceive the costs, heavy regulations and controls as more important than the comparative advantages that the country offers - amongst others, excellent land, skilled and cheap human resources and an advantageous geographical position. In addition to this, corruption and changing legislation also prevent investors from bringing money to the country. At the same time, the government lacks the financial means to improve the economic environment in Moldova in order to attract investors. Therefore, one of the means of the Moldovan government to break the vicious circle is legislation that provides for clear and firm legal conditions and attracts investors to the country. The draft Law on Public-Private Partnerships is an essential part of the reform process and the implementation of the PCA and ENP.

\section{Development of the draft Law on Public-Private Partnerships in Moldova}

The draft Law on PPPs in Moldova has been developed by the Ministry of the Economy in order to solve the problem of weak state structures in the Republic of Moldova. However, before the law can be passed by Parliament, it has to be reviewed for its compatibility with Community legislation. This obligation, stated in the Law 'On Legislative Acts'4 and the Law 'On Normative Acts'5 of the Government of the Republic of Moldova, was introduced in the course of the implementation of the Partnership and Co-operation Agreement and the European Neighbourhood Policy. These instruments mainly define the policy of the European Union towards Moldova that aim at a deeper political relationship and economic integration with the neighbours of the European Union.

\section{The Centre for Legal Approximation}

The statement of compatibility that is also the basis for this analysis was issued by the Centre for Legal Approximation. The Centre for Legal Approximation is the result of the obligation to take into account Community legislation during the elaboration of

4 Law on Legislative Acts of the Republic of Moldova No. 780-XV as of 27 December 2001, Monitorul Oficial of the Republic of Moldova No. 36-38/210, dated 14 March 2002.

5 Law on Normative Acts of the Government and Other Central and Local Public Administration Authorities No. 317-XV, as of 18 July 2003, Monitorul Oficial of the Republic of Moldova No. 208-210/783, dated 3 October 2003. 
draft laws, as stated above. This also includes the obligation to insert information on EU sources in the justification note by the time each draft is presented for adoption.

In order to fulfil these obligations, the Centre for Legal Approximation was set up by Government Decision No. 190/2007. The main competences of the Centre are to elaborate, co-ordinate and monitor the National Plan for Legal Harmonisation and to issue statements of compatibility on all the draft legislation with European Community relevance before these are passed to the government or Parliament for adoption.

The Centre for Legal Approximation will also introduce a harmonisation database that will monitor the harmonisation process and that will contain all the EC legislative sources, in English and Moldavian languages.

\section{Current developments}

The draft Law on PPPs is currently being discussed in the Parliament of the Republic of Moldova. It is expected that the draft will be referred back to the Ministry of the Economy for changes and improvement.

\section{Analysis of the draft Law on Public-Private Partnerships}

In the following sections a short overview of the main points of the draft Moldovan Law on Public-Private Partnerships will be given.

\section{Aim and basic principles (Preamble and Articles 4-11)}

The aim of the law is to attract private investment for the realisation of projects of public significance and to enhance the efficiency and quality of services and administrative tasks, as well as to increase the efficiency of the operation of public property and funds.

The draft Law is based on eight principles providing rights and obligations of the public authorities.

\section{a) The principle of equality (Article 4)}

This principle guarantees the equality of all competitors during all stages of selection, and prohibits all types of discrimination. In any cases of conflict of interest involving members of the procurement committee, the necessary steps have to be taken in order to prevent the respective member of the committee from participating in any decisionmaking process. Decisions made by these members are void.

\section{b) The principle of transparency (Article 5)}

The public partner is to ensure an objective selection process of the private partner. All information necessary for the private partners must be distributed by the public partner equally for all competitors during the establishment of the partnership. The commission selecting the partner has to confer publicly.

\section{c) The principle of proportionality (Article 6)}

According to this principle, the private partner's involvement must be limited to what is necessary to achieve the objectives of the agreements. The public partner is allowed to influence the private partner only in so far as it is necessary and is in compliance with the aim pursued. In case the public partner exceeds its competences, the private 
partner has the right to demand compensation in respect of all resultant losses, including missed profit.

\section{d) The principle of balance (Article 7)}

This principle is based on the balance of rights and duties for both the private and public partner. The public partner is obliged to act for the public benefit. In addition to this, the principle of balance also implies that the private partner has to bear a certain part of the financial and other risks of the project. If the agreement between both partners states that the risk will be borne solely by the public partner, the agreement can not be regarded as a public-private partnership.

\section{e) The principle of competition (Article 8)}

The public partner must ensure free and fair competition during the selection process.

\section{f) The principle of freedom of contract (Article 9)}

Both partners can freely determine their rights and duties unless otherwise stated by law. Consequently, both partners can agree on the use of arbitration.

\section{g) The principle of interaction (Article 10)}

Within the scope of the partnership, the public partner must assist the private partner in attaining the documents necessary to achieving the aim of the partnership. Therefore, it is forbidden to constrain the private partner to certain actions by withholding required documents.

\section{h) The principle of subsidiary liability (Article 11)}

Within the scope of the partnership, the public partner is subsidiarily liable for any damage which the private partner causes to third parties in the course of the performance of the project. However, under certain circumstances the public partner can be confronted with claims regarding compensation for loss caused by the private partner. These expenses can be reclaimed afterwards from the private partner. Projects should be realised continuously and smoothly.

\section{Forms of PPP implementation in the Law (Articles 18-24)}

The draft Law provides different standard contract types, a brief introduction to which follows.

\section{a) The service agreement (Article 20)}

This type of contract regulates the rendering of services in the municipal economy, the fundamental restoration and operation of infrastructure objects, the calculation of used resources and the issuing of invoices to consumers.

The maximum validity period of a service agreement is three years.

\section{b) The contract on the administration of trusts (Article 21)}

Hereby the suitable management of public property is ensured. The public partner commits to paying the private partner based on the quality and results of its manage- 
ment. The public partner transfers all related risks concerning the management and the technical system to the private partner, unless otherwise required by law.

The public partner is responsible for charging fees for rendered services and bears the risk associated with the payback of the investment, unless otherwise agreed on in the contract.

The maximum validity period of this type of contract is five years.

c) The engagement/lease contract (Article 22)

This type of contract regulates the transfer of public property for temporary ownership and operation. The private partner is responsible for operating the property according to its intended purpose, including the charging of fees and the rendering of services.

The maximum validity period of this type of contract is fifteen years.

\section{d) The concession contract (Article 23)}

The private partner is awarded the right temporarily to use public property and services.

The maximum validity period of this type of contract is fifty years.

There are several forms of concession contract. However, Article 23 does not clearly outline and distinguish between them and there are several contradictions.

i. Design, build and operate (DBO) (Article 23 para. 3a)

The private partner builds and operates the object and has to transfer it to the public partner, in full working order, after a maximum period of fifty years. The private partner may cover all expenses. After the expiry of the deadline, the object of the PPP has to be gratuitously transferred to the public partner in an operative condition and not burdened by any mortgage or obligation.

ii. Build, operate and restore (BOR) (Article 23 para. 3b)

This contract differs from the aforementioned DBO only insofar as the private partner is obliged to cover all expenses.

iii. Build, operate and transfer (BOT) (Article 23 para. 3c)

This contract differs from the aforementioned DBO and BOR only insofar as the private partner is entitled to charge fees with the intention of compensating for investment and covering charges on service, and with the additional purpose of making a profit.

iv. Build, transfer and operate (BTO) (Article 23 para. 3d)

The private partner builds the object, then immediately transfers ownership to the public partner which, in turn, transfers right of use to the private partner.

v. Lease, develop and operate (LDO) (Article 23 para. 3e)

According to this contract, the private partner obtains the possession of the object and has to pay it off in instalments within a maximum period of fifty years. The public 
partner is entitled to obtain revenues from charged fees. After the object has been paid off, ownership is transferred to the public partner.

This paragraph appears to contain a mistake. After the object has been paid off, ownership should be transferred to the private partner.

vi. Restore, operate and transfer (ROT) (Article 23 para. 3f)

The private partner must restore the object and may then operate it for a maximum period of fifty years, after which it must transfer it to the public owner in functional condition and without any burden.

\section{e) The co-operation contract (Article 24)}

The co-operation model consists of the joint creation of either a civil company without the creation of a legal entity or a limited liability company.

\section{Modified circumstances of the PPP (Articles 25-29)}

Articles 25-29 describe other provisions that should be regulated in a PPP contract such as the subject terms, the liability of the parties, the treatment of information and intellectual property. In case the parties have not settled on certain points, Articles 2529 provide for additional regulations. For example, intellectual property rights gained during the partnership belong to the public partner if no other provisions exist in the PPP contract.

Article 28 regulates the division of risks and obligations in the partnership. The private partner is responsible for the implementation of the project and all necessary requirements concerning management, while the public partner bears the risks for the partnership of changing circumstances. In case one of the parties violates the contract, the other party has the right to cancel the contract and demand damages.

\section{The establishment of the PPP and the choice of private partner (Articles 30-38)}

Articles 30-38 describe the procedure for the selection of the private partner, the establishment of a committee, the consequences of any conflicts of interest and the formal requirements of the PPP contract and the formation of such.

\section{a) Selection of the private partner}

The selection procedures have to be carried out in a transparent and non-discriminatory way. PPP contracts without tenders to select the private partner can only be allowed if the subject of the contract is a state secret (Article 31). The draft Law on PPPs states in a detailed way what information has to be published. Furthermore, the commission to assess the best offer has to be elected carefully and should consist of at least three people. The principle of equality applies here especially with regard to possible conflicts of interest.

\section{b) Conclusion of the contract}

As soon as the best offer and the most suitable private partner have been selected by the committee, the contract is delivered to the winner of the tender. Contract negotiations then take place. Under Article 38 of the draft Law, a copy of the final agreement 
has to be forwarded to the Ministry of the Economy and Trade in order to enter the contract into a special register for public-private partnerships.

\section{Guarantees and risks (Articles 39-41)}

Articles 39 and 40 establish the guarantees issued to each of the private and public partners by the other contracting party. These regulations oblige the private and public partners to consider the interests and rights of the other party. Liability for damages inflicted in the course of a breach of contract is stated. Article 41 describes the public partner's duty to disclose any risks associated with the project.

\section{Summary statement}

The draft law on PPPs of the Republic of Moldova comprises basic principles and the general obligations of the parties. Rights and responsibilities are not strictly regulated but a lot of room is left to the contracting freedom of the public and private parties. The principles stated in the draft Law represent a modern understanding of competition and public-private partnerships. Furthermore, the regulations being summed up in one body of law will also facilitate the contracting procedures as the private partner can estimate the risks and obligations deriving from a public-private partnership in a single glance. Therefore, the draft can be seen as providing a solid basis for the efforts of the Government of the Republic of Moldova to attract private investors to the public sector and thus improve state structures.

\section{The European legal framework for public-private partnerships}

At the European level, some debate has risen about the legal qualification of PPPs and their economic function. ${ }^{6}$ Facing the increased use of PPPs in the member states of the EU, the European Commission published a Green Paper ${ }^{7}$ on PPPs in $2004^{8}$ which deals with the legal implications of the use of PPPs at Community level. This Green Paper serves in the first sub-section below as a starting point in order to present the legal framework of the EU; in the second sub-section, recent developments in EU law with respect to the special procedure of the competitive dialogue and 'in-house' contracts will be outlined.

\section{Green Paper of the European Commission on PPPs}

In order to present the European legal framework for PPPs, the European Commission identifies the characteristic elements of PPPs and the Community rules relevant to the subject.

6 See in this respect, for example, Säcker (2007) 'Die Auswirkungen der Rechtsprechung des EuGH zu In-House-Geschäften auf Public-Private-Partnerships' in: Wettbewerb in Recht und Praxis: 282.

7 Green Papers are discussion papers addressed to interested parties, who are invited to participate in a process of consultation and debate. These may give the impetus to subsequent legislation. See in this respect the explanation of the Commission, available at: http://europa.eu/documents/comm/index en.htm [last accessed: 11 November 2007].

8 European Commission (publ.) op. cit. 


\section{Characteristic elements of PPPs}

There is no general definition of PPPs in EC law. ${ }^{9}$ Dealing with the subject, the European Commission has identified four criteria so as to define PPPs within a typological approach. ${ }^{10}$ This characterisation is generally accepted and serves as a basis for the assessment of PPPs in EU law. ${ }^{11}$

\section{a) Relatively long, project-based co-operation}

The first criterion to characterise PPPs is the relatively long duration of the relationship. The relationship involves co-operation between the public partner and the private partner on different aspects of a project. It includes co-operation during its planning and execution.

\section{b) Funding of the project}

The second criterion that characterises PPPs is the method of funding of the project. Normally, the funding is provided in part from the private sector and can be assured by means of complex arrangements between the various players. However, this does not exclude the possibility that substantial public funds may be added to the private funds.

\section{c) Repartition of participation in the project}

Thirdly, PPPs present a special repartition of the participation of the actors in the project. The private economic operator plays an important role in the project and participates in its different stages (design, implementation, completion, funding). The public partner is in charge of the delimitation of the tasks. It concentrates on defining the objectives to be attained in terms of the public interest and takes responsibility for monitoring compliance with these objectives. This may include, on behalf of the public partner, control over the quality of the services provided and the establishment of a determined pricing policy.

\section{d) Distribution of the risks}

The fourth and last criterion to characterise PPPs is the distribution of risks between the public partner and the private partner. Risks traditionally borne by the public sector are, in part, transferred to the private partner. The precise distribution of the risks is determined on a case-by-case basis. It does not entail necessarily that the private partner shoulders the major share of the risks linked to the project but, rather, that the distribution of risk is determined according to the willingness and ability of the parties to deal with the risk. ${ }^{12}$

9 Säcker op. cit: 282.

10 European Commission (publ.) op. cit: 3.

11 Säcker op. cit: 282 et seq.

12 See, on these four criteria in general, European Commission (publ.) op. cit: 3; and also for a summary Säcker (2007) op. cit: 282 et seq. 
Regulations of the European Community relevant to PPPs

Based on the presented definition of PPPs, a general legislative framework can be established and a distinction drawn between purely contractual PPPs and institutionalised PPPs.

\section{a) The general legislative framework}

In order to assess the general legislative framework for PPPs in the EU, some general remarks will first be made before turning to the relevant rules and principles resulting from the EU Treaty ${ }^{13}$ and EU regulations and directives.

\section{i. Generalities}

Community law does not lay down any special rules or homogeneous regulations covering the phenomenon of PPPs. ${ }^{14}$ However, any act whereby a public entity entrusts the provision of an economic activity to a third party must respect the rules and principles resulting from the EU Treaty and European directives or regulations, as the rules on the internal market apply to any economic activity. Public authorities are bound to comply with the rules on public contracts and concessions, even if the service is in the general interest. ${ }^{15}$ However, it has to be pointed out that Community law on public contracts and concessions is, in general neutral, as regards the choice by member states to provide a public service themselves or to engage in a PPP. ${ }^{16}$

ii. Rules and principles resulting from the EU Treaty

From the perspective of public contracts and concessions, the EU Treaty sets out freedom of establishment ${ }^{17}$ and the freedom to provide services. ${ }^{18}$ These freedoms encompass, in particular, the principles of transparency, equality of treatment, proportionality and mutual recognition. ${ }^{19}$ Even though the legislative framework governing the choice of private partner has been the subject of Community co-ordination at several levels and degrees of intensity, these principles are the minimum base which has always to be respected. From these principles derives the overriding aim of further Community legislation, which is to avoid both the risk of preference being given to national private sector partners and a choice based on other than economic considerations, ${ }^{20}$ as this is seen as an obstacle to the functioning of the internal market.

\section{iii. Regulations and directives}

In general, the Commission has adopted measures, in certain fields, to remove barriers to PPPs. Moreover, the adoption of a statute for a European company in a Council

13 Treaty establishing the European Community (consolidated version as amended by the Treaty of Nice), Official Journal of the EC OJ C 325/33, 24 December 2002.

14 European Commission (publ.) op. cit: 5.

15 ibid.p. 4.

16 European Commission (publ.) op. cit: 7.

17 See, especially Article 43 EU Treaty, under Chapter 2, entitled 'Right of establishment' (Art. 43 et seq.).

18 EU Treaty Art. 49 et seq.

19 European Commission (publ.) op. cit: 5.

20 ibid. 
regulation ${ }^{21}$ can be seen as facilitating trans-European PPPs. However, the main body of Community regulation concerning PPPs consists of directives relating to the co-ordination of procedures for the award of public contracts. ${ }^{22}$ In certain sectors, and particularly in transport, the organisation of PPPs is subject to specific sectoral legislation. $^{23}$

\section{b) Purely contractual PPPs and institutionalised PPPs}

In general, two major models of PPP can be identified which raise specific questions regarding the application of Community law on public contracts and concessions. ${ }^{24}$

\section{i. Purely contractual PPPs}

PPPs of a purely contractual nature are partnerships between the public and the private sector which are solely based on contractual links between the different players. One of the best-known models is the concessive model, which raises specific questions in Community law.

\section{The concessive model}

In the concessive model, a direct link exists between the private partner and the final user. The private partner provides a service under the control of the public partner. The method of remuneration for the joint contractor consists of charges levied on users which are, if necessary, supplemented by subsidies from the public authorities. The definition given by national law or by the parties has no impact on the interpretation of these contracts for the application of Community law on public contracts and concessions.

\section{Community law applicable to the concessive model}

The EU Treaty sets out several obligations for the public authority. They consist primarily in fixing the rules applicable to the selection of the private partner, adequate advertising of the intention to award a concession and compliance with the principle of the equality of treatment of all participants throughout the procedure introducing competition between the operators. The selection has to be based on objective, nondiscriminatory criteria. Accordingly, Community secondary legislation mainly concerns the phases of the award of a contract. In the field of public works, public supply or public services, Community directives lay down detailed rules particularly relating to advertising and participation, limiting the choice of the public authorities over the award of the contract.

\section{Co-ordination of procedures}

The EC has adopted a directive on the co-ordination of procedures for the award of public works contracts, public supply contracts and public service contracts ${ }^{25}$ which

21 Council Regulation (EC) No. 2157/2001, 8 October 2001.

22 European Commission (publ.) op. cit: 5.

23 ibid.

24 ibid.p. 8.

25 Directive 2004/18/EC Official Journal of the European Union, L 134/114, 30 April 2004. 
intends to simplify the legal regulation on the matter. ${ }^{26}$ The scope of application of the directive is limited to contracts above certain threshold amounts. ${ }^{27}$ Furthermore, some contracts are excluded from the scope of application: ${ }^{28}$ for example, contracts in the water, energy, transport and postal services sectors, ${ }^{29}$ secret contracts and contracts requiring special security measures ${ }^{30}$ and service concessions. ${ }^{31}$ However, in opposition to public service concessions, it basically applies to public works concessions. ${ }^{32}$ Once the directive is in operation, it contains detailed provisions on the award and conduct of procedures, including rules on advertising and transparency.

\section{ii. Institutionalised PPPs}

Institutionalised PPPs are co-operations within a distinct entity held jointly by the public partner and the private partner. ${ }^{33}$ These 'joint PPPs' permit a relatively high degree of control over the development of projects through the presence of the public partner in the body of shareholders and in decision-making bodies. However, as the joint creation of such entities must, in particular, respect the principle of the free movement of capital, public authorities cannot make their position as shareholder contingent on excessive privileges which do not derive from a normal application of company law. With respect to the legal uncertainty arising from the subject, the European Commission is not yet considering a legally-binding regulation of the matter but prefers to give a subsequent interpretative communication. ${ }^{34}$

\section{Recent developments: competitive dialogue and 'in-house' contracts}

In the current discussion on PPPs in EU law, two aspects have mainly to be considered: the introduction of the procedure of competitive dialogue in public procurement; and the legal qualification of 'in-house' contracts.

26 Whether this directive effectively achieves this aim is debatable, as it contains a great number of wide provisions. See in this respect: Knauff (2004) 'Die Reform des europäischen Vergaberechts' in Europäische Zeitschrift für Wirtschaftsrecht: 141 et seq.

27 According to Article 7 of Directive 2004/18/EC, these are: $€ 162000$ or $€ 249000$ for public supply and service contracts, depending on the contracting authority, and $€ 6242000$ for public works contracts.

28 See Title II Chapter II Section 3 'Excluded contracts', Art. 12 et seq. of Directive 2004/ 18/EC.

29 Art. 12 of Directive 2004/18/EC.

30 Art. 14 of Directive 2004/18/EC.

31 Art. 17 of Directive 2004/18/EC.

32 Art. 56 et seq. of Directive 2004/18/EC.

33 European Commission (publ.) op. cit: 8 and p. 18 et seq.

34 The European Commission announced an interpretative communication but has not yet taken this initiative. See for the announcement: Communication from the Commission to the European Parliament, the Council, the European Economic and Social Committee and the Committee of the regions on Public-Private Partnerships and Community Law on Public Procurement and Concessions, 15 November 2005, COM(2005)569 final and, for current developments: http://ec.europa.eu/internal market/publicprocurement/ppp en.htm [last accessed 20 November 2007]. 


\section{Competitive dialogue}

Facing the complexity of the contractual relationships underlying PPPs, the competitive dialogue procedure has been introduced in EU law in order to provide the necessary flexibility in public procurement. ${ }^{35}$ Thus, this procedure may be applied when the contracting body is objectively unable to define the technical means and/or the legal and financial form of the project. The public authority may, then, open a dialogue with the candidates for the purpose of identifying solutions. At the end of the dialogue, the candidates will be invited to submit their final tender. Being less restrictive than other classical procedures, this new procedure meets the needs of the flexibility of public authorities with respect to particularly complex partnerships.

\section{'In-house' contracts}

In-house contracts are characterised by a public authority entrusting a task to a third entity over which it exercises a control similar to that which it exercises over its own departments, and that the essential part of the activities are carried out under the control of the public entity. Basically, EU law on public contracts and concessions does not apply to these constellations. Therefore, in cases where a public authority has the described amount of control, no competitive procedure is required when entrusting the joint entity with the relevant task. It has to be stated, though, that the approach of the European Court of Justice has been very restrictive on in-house contracts and that, therefore, PPPs fall only in very limited constellations under this exception. ${ }^{36}$

\section{Legislation on public-private partnerships in Germany}

Public authorities are facing increased budget constraints and an increased recourse to PPPs $^{37}$ in Germany can be observed. ${ }^{38}$ At present, there is no homogenous regulation of PPPs in German law: PPPs still occur within a complex legal framework even if some legal restraints have been addressed in the so-called PPP Acceleration Act. ${ }^{39}$

35 See Article 29 of Directive 2004/18/EC Official Journal of the European Union L 134/ 114, 30 April 2004.

36 Säcker op. cit: 282 (298); European Commission (publ.) op. cit: 20; and one of the recent judgements on this matter of the European Court of Justice: Judgement, 11 May 2006, Case C-340/04 Carbotermo and Consorzio Alisei [2006] ECR I-4137.

37 The official German term is Öffentlich Private Partnerschaft (ÖPP). However, the English term PPP is widely used.

38 See, for example, the survey of the German Institute of Urban Affairs (Deutsches Institut für Urbanistik) on PPP projects for related infrastructure measures in: German Institute of Urban Affairs (ed.) (2006) Public Private Partnership Projects in Germany - A survey of current projects at federal, Land and municipal level Summary: 3; Nickel (2004) 'Public Private Partnerships: Ein Ausweg aus der Finanzkrise der öffentlichen Hand?' in Zeitschrift für Bau- und Vergaberecht: 9 et seq; Fleckenstein (2006) op. cit: 75 et seq.

39 German federal law on the acceleration of the implementation of public private partnerships and on the amelioration of the legal framework for public private partnerships (Gesetz, zur Beschleunigung der Umsetzung von Öffentlich Privaten Partnerschaften und zur Verbesserung gesetzlicher Rahmenbedingungen für Öffentlich Private Partnerschaften), promulgated on 7 September 2005, Official Journal of the German Federal Republic (Bundesgesetzblatt) I, 2676; it entered into force on 8 September 2005. 


\section{Complex legal framework for PPPs in Germany}

In order to analyse the legal framework for PPPs in Germany, first an overview over the different PPP models will be given and then relevant legal norms applicable to PPPs will be outlined with respect to civil contract law and public procurement law.

\section{The different PPP models in Germany}

Scholars distinguish seven different PPP models ${ }^{40}$ in Germany, although elements of these models can be combined. ${ }^{41}$ This underlines the flexibility of PPPs which can be adapted to projects at hand. In the following, three examples are given.

\section{a) The operator model (Betreibermodell)}

This model is the most popular in practice. In the operator model, the public authority entrusts a private entity (the operator) with the construction and management of a building. The private investor owns the building and has the function of operator (Betreiberfunktion). The public authority bears the responsibility for the provision of the service and receives the user fees. The refinancing of private funding is carried out by the public entity and lasts, on average, twenty to thirty years depending on the contract. These operator models also include the so-called DBFO models (design, build, finance, operate) or the BOT models (build, operate, transfer)..$^{42} \mathrm{~A}$ well-known example is the construction and operation of a toll system for heavy goods vehicles ( $L K W$ Mautsystem) on German autobahns.

\section{b) The co-operation model (Kooperationsmodell)}

The co-operation model consists in the joint creation of an undertaking under civil law, in most cases a limited liability company. The purpose of the company is to carry out a public task. It is a form of institutionalised PPP. Compared to the operator model, the public entity has more control over the execution of the task as it has rights on information and influence on decision-making processes within the undertaking, according to company law. The created company can also carry out the construction of a building and assume the subsequent management of the facility. Examples are found in the areas of waste removal and water supply.

\section{c) The concession model (Konzessionsmodell)}

The concession model is characterised by a direct relationship between the private partner and the user. The public authority authorises the private entity to carry out a task which the private entity bears the risk of the refinancing of its investments by collecting fees directly from users. Such a concession model is applied, for example, for the construction and operation of a tunnel under the River Warnow.

40 See, for example Wohland (2007) 'Public Private Partnership - Rahmenbedingungen und rechtliche Grundlagen' in KommunalPraxis spezial: 64 (65).

41 See, for example, Bloeck (2007) 'Private Public Partnerships - Ein Überblick über die Möglichkeiten öffentlich-privater Zusammenarbeit und ihre rechtlichen Rahmenbedingungen' in KommunalPraxis spezial: 60 (62 et seq.).

42 Nickel (2004) op. cit: 9 (10). 


\section{$P P P$ and civil contract law}

PPPs are based upon civil law contracts. ${ }^{43}$ In German civil law, a basic freedom of contract exists and the German Civil Code (Bürgerliches Gesetzbuch, in the following: BGB) does not provide a legally binding catalogue of types of contract. PPP projects are based on a multitude of stipulations which can be sub-divided into a main agreement (PPP-Projektvertrag or PPP-Vertragsbündel, in the following: PPP contract) and incidental contracts ${ }^{44}$ (Nebenverträge). ${ }^{45}$ Under civil law, the PPP contract is a contract of its own kind which may include, depending on the project, elements of contracts regulated by the BGB. ${ }^{46}$ However, in the absence of special provisions in the contract which provides the basis for a PPP, the principles of the contract law of the BGB apply.

\section{a) Modified circumstances of the PPP}

During a PPP, the overall circumstances of the project may be subject to change. Especially considering that the average duration of a PPP is ten to twenty years, substantial changes may occur affecting the interests of the different partners. In general, contracts contain special provisions dealing with different forms of the significant changes of circumstances which permit the modification of the initial contract and which eventually, if modification is not possible, foresee its cancellation. ${ }^{47}$ In the absence of special regulations, this derives also from the BGB where, under the provision of interference with the basis of the transaction, ${ }^{48}$ the disadvantaged party may withdraw from the contract if the adaptation of the contract is not possible or cannot be reasonably expected. ${ }^{49}$

\section{b) Performance not in conformity with the contract}

The obligations and rights deriving from a contract vary in consideration of its legal qualification. Due to the complexity of the contractual relationship underlying a PPP, it is often difficult to assess the precise legal qualification of the contract. The legal qualification of the contract (or elements of the contract) may substantially affect the rights and duties of the partners. These vary with respect to the legal qualification of the PPP contract. Two brief examples of the possible qualification of PPP contracts may be given.

43 Pencereci (2007) 'PPP-Modelle und Leistungsstörungen' in KommunalPraxis spezial: 101 (103).

44 Depending on the PPP project, these incidental contracts may be, for example: company agreement (Gesellschaftsvertrag), loan agreement (Darlehensvertrag) or a contract for work (Werkvertrag).

45 Schaller (2007) 'Der Wettbewerbliche Dialog - eine besondere Vergabeart beim PPP (ÖPP)-Vertrag' in KommunalPraxis spezial: 98.

46 ibid. p. 98.

47 Pencereci (2007) op. cit: 101 (103).

48 Section 313, BGB.

49 ibid. para. 3. 


\section{i. Contract for work (Werkvertrag)}

If the PPP contract can be qualified as a contract to produce work, the rights and duties of the partners derive from Title 9 of the BGB. The subject matter of this type of contract is the achievement by work or by service of an outcome. ${ }^{50}$ One example would be the construction of a building by a private partner which is destined to be owned by the public partner. In the case of defects, the rights of the public partner are set out in Section 634 of the BGB. These may include, for instance, the right to demand performance, to remedy the defect and demand reimbursement, or to withdraw from the contract..$^{51}$

\section{ii. Service contract (Dienstvertrag)}

PPP contracts may, in some cases, also contain elements of a service contract. In contrast to contracts to provide work, an outcome is not required other than the delivery of the promised services. Different rules apply to this type of contract as, for example, these contracts may be terminated without notice for a compelling reason. ${ }^{52}$

\section{PPP and public procurement law}

The legal qualification of the PPP contract is also important in public procurement law. Different official contracting terms (Verdingungsordnung) apply to the award of construction contracts (Bauauftrag) and service contracts (Dienstleistungsauftrag). A PPP contract cannot be awarded on the basis of two different official contracting terms at the same time. ${ }^{53}$ Furthermore, in the presence of a concession under which the partner does not receive remuneration but a special right to utilisation, the official contracting terms for the award of construction performance (contracts Part A: Vergabe- und Vertragsordnung für Bauleistungen Teil A) set out specific rules for public works concessions (Baukonzessionen), whereas no special rules exist for service concessions (Dienstleistungskonzessionen). The distinction between construction contracts and service contracts was particularly difficult with regard to complex PPP contracts, so the PPP Acceleration Act addressed this matter and now - despite operating services being outweighed as far as cash value is concerned - construction work may be seen as the main item of the contract in most cases. ${ }^{54}$

50 ibid. section 631 para. 2.

51 ibid. section 634.

52 ibid. section 626.

53 Schröder (2007) 'PPP sicher vergeben - Vergaberechtliche Besonderheiten bei PPP-Projekten' in KommunalPraxis spezial: 94 (95).

54 Lohmann (2006) The PPP Acceleration Law in Germany and its Effects on Current Practice p. 4 et seq., available at: http://www.ibl.uni-stuttgart.de/02institut/pdf/lohmann/ Paper Eres 2006 Lohmann Tatjana.pdf [last accessed 18 November 2007], but see also Schröder (2007) op. cit: 94 (95), who still sees substantial problems of interpretation. 


\section{The Public-Private Partnership Acceleration Act ${ }^{55}$}

In general, German law does not preclude the use of PPPs, but some regulations and legal uncertainties have hindered the development of PPPs at various levels. ${ }^{56}$ In order to foster and accelerate the use of PPPs, the PPP Acceleration Act was adopted in 2005. This Act takes the form of a so-called 'article act' (Artikelgesetz), which is not a homogenous regulation of the whole matter but which amends and modifies existing regulations, e.g. the Law Against the Restraint of Competition (Gesetz gegen Wettbewerbsbeschränkungen); the Regulation on the Award of Public Contracts (Vergabeverordnung); and federal budgetary regulations (Bundeshaushaltsordnung) ${ }^{57}$ It is one of the few German acts that mentions the term PPP, although without providing a legal definition. ${ }^{58}$ The two main changes concern public procurement law, in which the procedure of the so-called competitive dialogue is introduced according to EC law; 59 and federal budgetary law, in which the transfer of public real estate is facilitated. ${ }^{60}$

\section{Legislation on public-private partnerships in the Russian Federation}

The development of PPPs ${ }^{61}$ in the Russian Federation is a means of the promotion of foreign private investment by the government. ${ }^{62}$ As in western Europe, the will for a mobilisation of private sector funding for traditionally under-financed areas, such as local infrastructure for example, is increasing. The main legal framework for PPPs in the Russian Federation is constituted by the Russian Civil Code and, in addition, since August 2005, by the federal law 'On Concession Agreements'. ${ }^{63}$

\section{Regulation of PPPs in the Russian Civil Code}

The main legal instrument on civil law in the Russian Federation is the Civil Code (in the following: CC). Despite the federal government having created a homogenous legal framework for PPP projects with a federal law on concession agreements, PPPs can still be concluded on a general basis under the provisions of the $\mathrm{CC}$, ${ }^{64}$ in which the form of 'state contract for the performance of contract works to meet state needs' (in the following: state contract) ${ }^{65}$ is of special relevance to PPP projects.

55 For an overview of the Acceleration Act, see Fleckenstein (2006) op. cit: 75; and, in English: Welch (2006) 'Public Private Partnerships in Germany' in Infrastructure Journal 37 available at: http://www.ijonline.com/pdf/2006springIJ/10PPPsinGermany.pdf; Lohmann (2006) op. cit: 4 et seq.

56 Fleckenstein (2006) op. cit: 75 et seq.

57 See, in general, Fleckenstein (2006) op. cit: 75 (76); for an overview of the amended acts in English, see: Lohmann (2006) op. cit: 4.

58 Fleckenstein (2006) op. cit: 75 (76).

59 See above section and, especially for Germany: Schaller (2007) op. cit: 98 et seq.

60 Lohmann (2006) op. cit.

61 The Russian term for PPP is государственно-частное nартнерство (gosudarst-

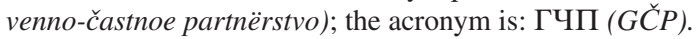

62 Tiede (2007) 'Rechtliche Rahmenbedingungen für Public Private Partnerships bei Infrastrukturprojekten in der Russischen Föderation' in Jahrbuch für Ostrecht: 55.

63 Official Journal of the Russian Federation 2005, No. 30 (Part II), Pos. 3126.

64 Tiede (2007) op. cit: 55 (56 et seq.).

65 See Civil Code, Art. 763 et seq. 
Generalities on PPPs and the Russian Civil Code

In the law of obligations, the CC provides several types of standard contract in obligation law, which can be applied to PPPs. Likewise in German civil law, the parties are basically free to close a contract, even if this contract does not meet the criteria of one of the standard types regulated by law. The parties may as well agree on a so-called mixed-type contract which combines elements of regulated standard contracts.

\section{The state contract for the performance of contract works (state contract)}

A possible legal basis for a PPP in the construction sector is the state contract. This is a special form of a works contract for state needs in the $\mathrm{CC}$ which does not exist in the $\mathrm{BGB}$, where no distinction is drawn between the parties to a contract in civil law.

\section{Russian Law 'On Concession Agreements'}

The aim and content of the Law on Concession Agreements is currently the most important legal basis for PPP models. ${ }^{66}$ The PPP model underlying the Law on Concession Agreements is the operator model ${ }^{67}$ Unlike the German PPP Acceleration Act, it is not an 'article act' amending existing regulations but something that aims to create a genuine legal basis for concession model PPPs in order to foster private investment. Therefore, it may be seen as a separate legal framework containing detailed provisions on the matter.

\section{Relationship between the Law 'On Concession Agreements' and the Civil Code}

The concession agreement is a special type of contract. It contains elements of various types of contract, the civil law regulations of which are applicable to the concession agreement as long as they do not contradict the law on concessions or the essence of the concession agreement itself.

\section{Generalities and definition of the concession}

Under the Law on Concession Agreements, the concessionaire has to be a private investor. Foreign natural persons cannot be concessionaires unless they register as individual entrepreneurs in the Russian Federation. Under a concession agreement, a grantee (either a Russian or a foreign legal entity, participants in a joint venture agreement or an individual entrepreneur) shall, at his or her own expense, create or reconstruct the concession facility owned by a grantor and then operate it. The grantor (either the Russian Federation, a constituent of the Russian Federation or a municipal unit) gives the grantee the right to possess and use the facility. However, the object of the concession never becomes the property of the concessionaire. ${ }^{68}$

\section{Objects of the concession}

Concession facilities may include the following types of immovable property: transport and municipal infrastructure; sea and river ports and vessels; airport infrastructure; pipelines and waterworks; public transport; and medical, recreational, sports or

66 Tiede (2007) op. cit: 55 (59).

67 ibid. p. 55 (65).

68 ibid. p. 55 (59). 
educational facilities. ${ }^{69}$ The list of immovable property subject to concession is exhaustive ${ }^{70}$ and does not include, for example, industrial objects such as mining facilities. In addition, the government has to decide for each type of concession object a standard concession agreement which shall provide legal certainty for investors as well as homogeneity in the economic areas throughout Russia. ${ }^{71}$

\section{Comparative analysis of the Moldovan, German and Russian legislation on public-private partnerships}

Even though some similarities exist concerning the legislation on PPPs in Moldova, Germany and the Russian Federation, substantial differences can also be observed.

\section{A common general framework?}

The legal measures analysed provide neither a concise legal definition of the term PPP nor a homogenous regulation of the matter. PPPs are characterised by a complex contractual framework which is, due to freedom of contract, governed by the contractual stipulations at hand. In general, civil law applies to the contracts in PPP projects. These projects are characterised by a large flexibility of contractual regulation, which is one of their advantages. At the European level, the PPP phenomenon has given rise to a debate on the necessary regulations, but no initiative is currently planned to regulate the whole matter. Nevertheless, some detailed norms already exist concerning special areas and issues, especially concerning public procurement procedures.

\section{A common aim but a different approach in the search for homogeneity and control}

A common need does exist for co-operation between the public and private sector in the form of PPPs, but the approach is different. In Germany, the legislative initiative currently limits itself to facilitating and accelerating the development of PPPs by partially amending existing regulations. This is also in line with EU law, where it is only particular additional requirements that have to be respected. Nevertheless, the price to pay is legal uncertainty on different matters in relation to PPPs and a fragmented landscape for PPPs at different levels of the Federal Republic. Similarly, the Moldovan draft Law on PPPs ensures freedom of contract, allowing the partners deliberately to determine their rights and obligations within a wide range of possible contract forms. Moreover, German legislation and the Moldovan draft Law on PPPs equally contain a catalogue of criteria to be considered in procurement procedures ensuring freedom of competition.

The Russian Federation, in the search for greater homogeneity and control, has adopted a federal law containing precise legal definitions and obligations which restrains the flexibility of PPPs in a substantial way. In addition, this amount of control is not in line with the general liberalisation tendency of the EU. The provision in the Law on Concession Agreements which precludes foreign natural persons from becoming concessionaires is discriminatory on the basis of nationality ${ }^{72}$ In this respect,

69 See Law on Concession Agreements (Art. 4 para. 1) for the detailed list.

70 Tiede (2007) op. cit, p. 55 (60).

71 ibid.

72 See Law on Concession Agreements (Art. 5 para. 1 no. 2). 
Russian law differs from both the German legislation and the Moldovan draft Law on PPPs.

\section{Compliance of the Moldovan draft Law on PPPs with EU law}

Community law does not lay down any special rules covering the phenomenon of PPPs. Therefore, the Moldovan draft Law on PPPs is not liable to oppose EU law. However, in 2004 the Commission presented a Green Paper on public-private partnerships and Community law on public contracts and concessions (COM(2004) 327). It is not legally binding itself, but this document reflects the current debate on the regulation of PPPs in the EU and its legal implications. ${ }^{73}$

\section{Treaty provisions relevant to PPP}

Articles 43 and 49 of the EU Treaty (freedom of establishment and freedom to provide services), encompassing the principles of transparency, equality of treatment, proportionality and mutual recognition, must be respected. It was seen above that the Moldovan draft Law on PPPs is already based on these principles (Articles 4-11).

Furthermore the principle of competition, defined in Article 8 of the Moldovan draft Law on PPPs, is in accordance with Articles 81, 82 and 86(3) of the EU Treaty (concerning the rules governing competition), although the excessive duration of some contract forms (up to fifty years) may be found potentially to contradict these.

\section{Secondary legislation relevant to PPPs}

\section{Directives co-ordinating procedures for the award of public contracts}

Two major directives regulate public procurement procedures for contracts which exceed certain thresholds in different areas:

\section{a) Directive 2004/17/EC}

Directive 2004/17/EC of the European Parliament and of the Council of 31 March 2004 co-ordinates the procurement procedures of entities operating in the water, energy, transport and postal services sectors.

The Moldovan draft Law on PPPs is not yet sufficiently concrete to be related to this directive, as it does not include material on specific sectors.

\section{b) Directive 2004/18/EC}

Directive 2004/18/EC of the European Parliament and of the Council of 31 March 2004 co-ordinates procedures for the award of public works contracts, public supply contracts and public service contracts.

The Moldovan draft Law on PPPs does indeed includes such forms of contract although these are not explored in this article.

73 For recent developments in this area: http://ec.europa.eu/internal market/publicprocurement/ppp en.htm [last accessed 15 December 2007]. 
Specific sectoral legislation

In certain sectors (i.e. the transport sector), the organisation of PPPs may be subject to specific legislation. ${ }^{74}$ Again, however, the Moldovan draft Law on PPPs is not at this point sufficiently specific to be related to such cases.

\section{Conclusion}

The legislative framework of PPPs has various implications. A rather new phenomenon in Germany, and an even more recent one in the Russian Federation, the legal implications of this tool are still to be explored. Even more so, this is true for the Republic of Moldova where the Law on PPPs is, so far, only a draft which, however, clearly reveals a tendency towards EU compliance. Too much rigidity of regulation can make PPPs less attractive, but so can legal uncertainty due to a lack of clarity. Concise contractual stipulations may be one solution, but they have to be embedded within a general framework. Critics rising against the initiatives of the European Commission on the grounds that, in Germany, a second version of the PPP Acceleration Act is being debated and that, in Russia, there are difficulties in implementing the Law on Concession Agreements due, among others, to the rigidity of standard concession agreements show that currently no general agreement has been reached with regard to the regulation of PPPs.

\section{References}

Bloeck, Oliver (2007) 'Private Public Partnerships - Ein Überblick über die Möglichkeiten öffentlich-privater Zusammenarbeit und ihre rechtlichen Rahmenbedingungen' in KommunalPraxis spezial: 61-63.

European Commission (publ.) (2004) Green Paper on public-private partnerships and Community law on public contracts and concessions $\operatorname{COM}(2004) 254$, April, available at: http://eur-lex.europa.eu/LexUriServ/site/en/com/2004/com2004_ 0327en01.pdf.

Fleckenstein, Martin (2006) 'Abbau von Hemmnissen für Public Private Partnership: Das ÖPP-Beschleunigungsgesetz' in Deutsche Verwaltungsblätter: 75-82.

German Institute of Urban Affairs (Deutsches Institut für Urbanistik) (ed.) (2006) 'Public Private Partnership Projects in Germany - A survey of current projects at federal, Land and municipal level', Summary, available at: www.difu.de/english/ occasional/06ppp.pdf.

Knauff, Matthias (2004) 'Die Reform des europäischen Vergaberechts' in Europäische Zeitschrift für Wirtschaftsrecht: 141-144.

Lohmann, Tatjana (2006) The PPP Acceleration Law in Germany and its Effects on Current Practice paper prepared for presentation at the $13^{\text {th }}$ European Real Estate Society Conference 7-10 June, available at: http://www.ibl.uni-stuttgart.de/ 02institut/pdf/lohmann/Paper Eres 2006 Lohmann Tatjana.pdf.

Nickel, Thomas (2004) 'Public Private Partnerships: Ein Ausweg aus der Finanzkrise der öffentlichen Hand?' in Zeitschrift für Bau- und Vergaberecht: 9-15.

74 See, for example, Green Paper of the Commission COM(2004)327, p. 5. 
Pencereci, Turgut (2007) 'PPP-Modelle und Leistungsstörungen' in KommunalPraxis spezial: 101.

Säcker, Franz Jürgen (2007) 'Die Auswirkungen der Rechtsprechung des EuGH zu In-House-Geschäften auf Public-Private-Partnerships' in Wettbewerb in Recht und Praxis: 282-298.

Schaller, Hans (2007) 'Der Wettbewerbliche Dialog - eine besondere Vergabeart beim PPP (ÖPP)-Vertrag' in: KommunalPraxis spezial: 98-100.

Schröder, Holger (2007) 'PPP sicher vergeben - Vergaberechtliche Besonderheiten bei PPP-Projekten' in KommunalPraxis spezial: 94-97.

Tiede, Wolfgang (2007) 'Rechtliche Rahmenbedingungen für Public Private Partnerships bei Infrastrukturprojekten in der Russischen Föderation' in Jahrbuch für Ostrecht: 55-68.

Welch, Jack (2006) 'Public-Private Partnerships in Germany: German budget deficits present investment opportunities' in Infrastructure Journal, Spring: 37-39, available at: http://www.ijonline.com/pdf/2006springIJ/10PPPsinGermany.pdf.

Wohland, Andreas (2007) 'Public Private Partnership - Rahmenbedingungen und rechtliche Grundlagen' in KommunalPraxis spezial: 64-68.

\section{Abbreviations and acronyms}

BGB German Civil Code (Bürgerliches Gesetzbuch)

EC European Community

ÖPP-BeschlG Public Private Acceleration Law (Gesetz zur Beschleunigung der Umsetzung von Öffentlich Privaten Partnerschaften und zur Verbesserung gesetzlicher Rahmenbedingungen für Öffentlich Private Partnerschaften)

PPP Public-Private Partnership 